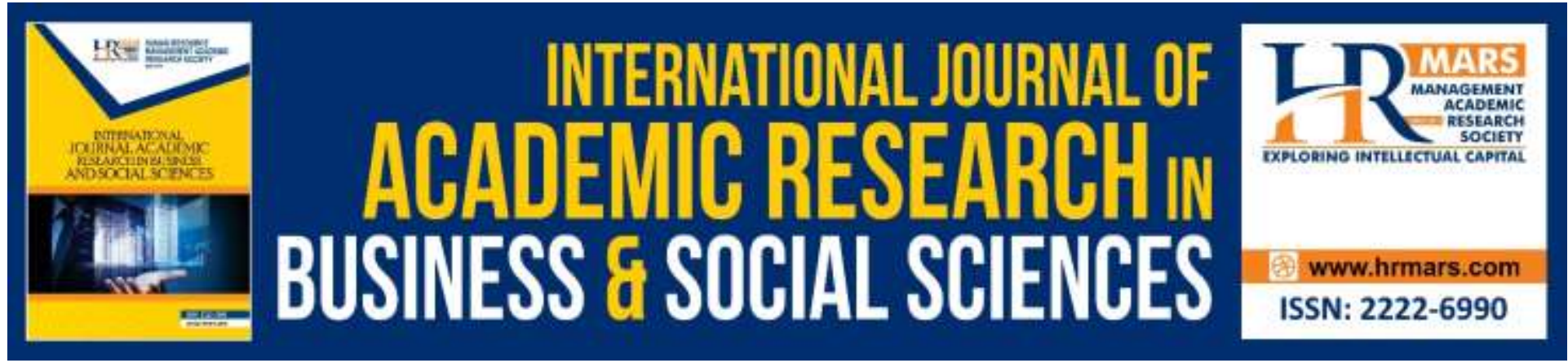

\title{
Distributed Leadership and Conflict Management Style of Generation Y Teachers: Malaysian Context
}

\author{
Marlia Jamail, Yahya Don and Farah Mohd Zain
}

To Link this Article: http://dx.doi.org/10.6007/IJARBSS/v9-i7/6335

DOI: $10.6007 /$ IJARBSS/v9-i7/6335

Received: 12 July 2019, Revised: 27 August 2019, Accepted: 30 August 2019

Published Online: 03 September 2019

In-Text Citation: (Jamail, Don, \& Zain, 2019)

To Cite this Article: Jamail, M., Don, Y., \& Zain, F. M. (2019). Distributed Leadership and Conflict Management Style of Generation Y Teachers: Malaysian Context. International Journal of Academic Research in Business and Social Sciences, 9(7), 1298-1320.

Copyright: (C) 2019 The Author(s)

Published by Human Resource Management Academic Research Society (www.hrmars.com)

This article is published under the Creative Commons Attribution (CC BY 4.0) license. Anyone may reproduce, distribute, translate and create derivative works of this article (for both commercial and non-commercial purposes), subject to full attribution to the original publication and authors. The full terms of this license may be seen at: http://creativecommons.org/licences/by/4.0/legalcode

Vol. 9, No. 7, 2019, Pg. 1298 - 1320

http://hrmars.com/index.php/pages/detail/IJARBSS

JOURNAL HOMEPAGE

Full Terms \& Conditions of access and use can be found at http://hrmars.com/index.php/pages/detail/publication-ethics 


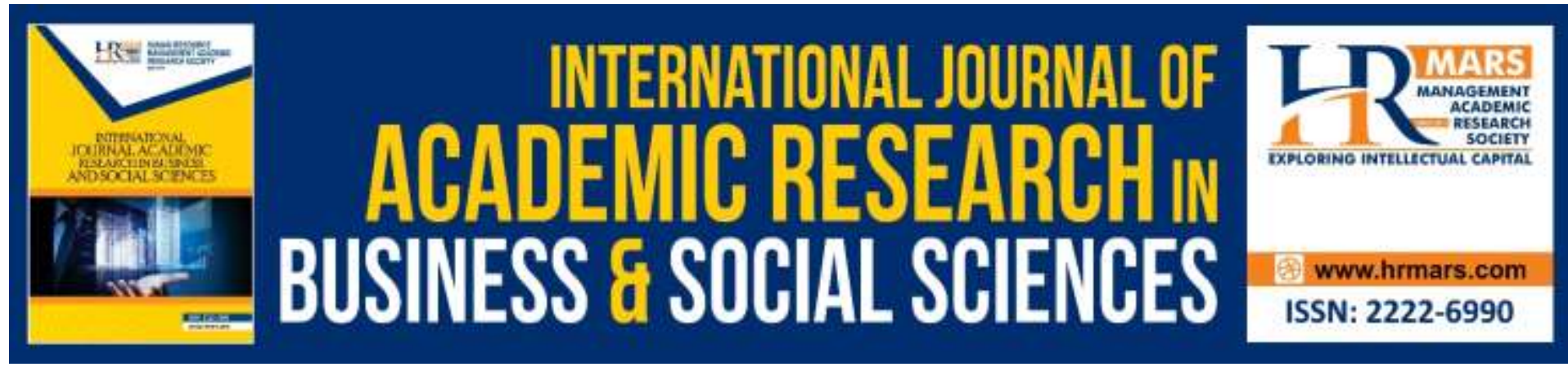

\title{
Distributed Leadership and Conflict Management Style of Generation Y Teachers: Malaysian Context
}

\author{
Marlia Jamail, Yahya Don and Farah Mohd Zain \\ College of Arts and Sciences, Universiti Utara Malaysia, 06010 UUM Sintok, Kedah Darul \\ Aman. \\ Email: marlia.jamail80@gmail.com
}

\begin{abstract}
The issue of generational gap causes the rise of conflict in school environment which will negatively impacted the motivation, job satisfaction and commitment of school teachers. Creative ways to manage conflict in the school is from the school leadership which would help school atmosphere to be more conducive as individuals react differently to the conflict they faced. This survey research is designed to identify distributed leadership and conflict management style at secondary schools in Kedah, that involved 370 teachers. This research focused on Generation $Y$ teachers on the relationship of distributed leadership and conflict management style. The Distributed Leadership Survey (DLS) which was introduced by Davis (2009) are used in this study to measure the distributed leaderships practices of the respondent. For conflict management style, the instrument from Rahim (1983), Rahim Organizational Conflict Instrument II (ROCl-II) Form A which consisted of 5 dimensions were used in this research. This instrument was used to measure the interpersonal conflict management style of generation $Y$ teachers towards their principals. The data were analyzed by using the statistical descriptive and inferential such as the mean, standard deviation, independent t-test, one-way ANOVA and Pearson correlation through SPSS Version 21.0. There is no significant difference between gender, qualifications and years of teaching experiences in practicing distributed leadership among generation $Y$ teachers. However, there is a positive and significant relationship between distributed leadership practices with conflict management style of the respondents. Overall, there were high average of correlation values between distributed leadership practices with the dimensions of conflict management. However, there is no significant relationship found between distributed leadership practices with dominating style of conflict management. The finding of this research could be used as guidelines for school leaderships in managing the generation $Y$ teachers in a best possible way to enhance the quality of teacher leaderships in school.
\end{abstract}

Keywords: Distributed Leadership, Teacher Leadership, Conflict Management and Generation Y Teachers 


\section{Introduction}

Changes in the education system is gaining attention around the world because of the main objective is to improve the quality of the education itself (Mahmud, 2011). The benchmark of the quality of educational performance in school is through the achievement of the student academic (Stronge et al., 2011). Leaders should be sensitive to these needs and changes to lead their organization and ensure the achievement of successful implementations (Majid, 2011). Malaysia Education Blueprint 2013 - 2025 (MEB 2013 - 2025) was then been introduced to improve the education system with major transformation (Ghani, 2013) where one of the shifts, focused on high quality school leadership. The fifth shifts of MEB is to 'Ensure High-Performing School Leaders in Every School', focused more on leadership training program to the principals. Principals need to have appropriate skills and knowledge to lead the transformation and manage the changes in the educational management efficiently.

Educational leaders should adopt a suitable leadership style that fit the demands and changes in the current needs in education (Rabindarang, Khuan \& Khoo, 2015) whereas leaderships in terms of hierarchal is less desired as it is no longer practical to practice (Rabindarang, Khuan \& Khoo, 2014). Distributed leadership is considered in line with the instructional leadership in MEB even though it is still in early implementation (Tahir et al., 2016) and it becomes the best practice and the best approach which may lead to successful of transformation in education system (Boon \& Tahir, 2003; Coleman \& Early, 2005; Harris, 2013; Rabindarang, Khuan \& Khoo, 2015; Yukl, 2000; 2002; Zakaria \& Kadir, 2013). Bush and Glover (2012) also agreed that the best practice of school leadership is shared leadership or distributed leadership.

The changes in the organization can cause depression, health problems, job stress and in quality work performance (Martin, 2007). Conflict that triggers in any organization need to be settled down. Conflict is almost impossible to avoid and when it happens, it will negatively affect team work and productivity of an individual in a long term (Rahim, 2001). Saiti (2015) noted that conflict often arise in school mainly because of interpersonal and organizational issues. Hence, the main role of school leaders is to identify the causes of conflict and they should be able to deal with the conflict efficiently (Terry, 1996). Creative ways to manage conflict would help the school atmosphere to be more conducive as individuals react differently to the conflict they faced (Saiti, 2015). Leaders who deal with conflict management in appropriate style are able to enhance team performance and reduce negative emotions of the followers in the organization (Ayoko \& Konrad, 2012).

\section{Problem Statement}

School leaders need to act as agents of change (Fullan, 2007), but numerous leaders still cannot lead the organization to implement changes to the transformation that goes into the education agenda of the country (Abdullah \& Kassim, 2011; Mansor, 2006). Principal is still viewed as the only person who is responsible for the school performance (Bush, 2011), principals are also being labeled as bureaucratic and hierarchical in handling schools (Abdullah, Dewitt \& Alias, 2013), principals have no time to supervise curricular (Tie, 2012) and teachers, principals unwilling to share their power (Carter et al., 2006), principals reluctant to practice distributed leadership (Hatcher, 2005) and principals are unable to detect appropriate teacher leadership in the school capacity (Nayeem, 2011) and thus 
creating conflicting interpretations of the practice of distributed leadership itself in school (Tahir et al., 2016).

The burdens and the role of the principals increasingly becomes more complex than before (Anthony, Said, Mohamad \& Mokhtar, 2015) even though the education system is agreeing that heroic leadership is no more relevant and should change to distributed leadership (Gronn, 2002). It is almost impossible for a person like a principal to handle all the chores alone in the school (Jones \& Harris, 2014) because principals are no longer considered as 'the only leader' in student achievement (Greenwood, 2011). Leadership in school also involved all the teachers (Gunter, 2001) as Sparks (2003) stated that teachers are the important change agents in creating effective schools. Bakar et al., (2015) stressed out that teacher leaderships should be put equally important agenda in the transformation of the education system as Katzenmeyer and Moller (2009) concluded that teacher leaderships is made up of high quality teachers.

In Malaysia, Tahir et al. (2016) stated 3 major challenges in performing the practice of distributed leaderships in school and they are that; a) teachers resist to lead, b) teachers lack of confidence when it comes to decision making, and c) teacher leaderships are difficult to be appointed. Often teachers assume that participating in leadership will give them more workloads and responsibilities (Tahir et al., 2016; Torrance, 2012), they also feel unprepared and incompetence to lead their colleagues (Lizotte, 2013), lack of motivation and confidence as they were not properly guided by the principal (Hulpia \& Devos, 2010). Thus, as a principal it is important to recognize the capacity of the teachers in school, for who is capable and who is not capable of leading (Matthews, 2014). Yusoff, Don and Ismail (2015) suggested that distributed leadership as the most important construct to form a quality school environment. School leaders need to understand the dimensions of distributed leadership practices so that teachers are prepared to accept leadership tasks at school.

Demographic aspects also need to be considered too in further research of distributed leadership (Daud et al., 2015; Don et al., 2015) as well as conflict management style. Leadership style are expected to be significant with conflict management style as both remain stable over the time (Hendel, 2005). Principals need to lead transformation in education system with effective leadership style and various conflict management style. However, most of the researcher on educational management and leadership, only encounter the principals and middle leadership, and less involving teachers in a formal leadership in schools. Murji (2015) and Sy (2010) noted that in education studies, school leaders are often focused on the principals rather than groups of followers such as the teachers. In Malaysia, teacher leaderships are less given attention and considered to be new in educational research and management (Bakar, Basri \& Fooi, 2015). Hence in this research, the respondents are focused more on the cohort of generation $Y$ teachers in terms of distributed leadership practices and interpersonal conflict management style.

Changes doesn't mean anything if every member of the organization does not change (Hall \& Hord, 2001). The key feature of leadership in facing changes is the willingness to change and commit to implement the changes within the organization (Santhindran, Chandran \& Borromeo, 2013). However, changes and transformation to the country's education system may also increase pressure (Rabindarang, Khuan \& Khoo, 2014) and thus created a destructive conflict in educational organization. Employees who are less clear about the changes that need to be done such as not understanding the areas of work that need to 
be prioritized, are easy to deal with conflicts because they do not understand what really need to be done (Yahaya et al., 2009).

In education system, conflict is a crucial topic (Rahim et al., 2001) as school is directly belongs to the service sectors that mostly pressured the teachers to achieve the standard quality performance of education in the best possible ways and maintained it (Shih \& Susanto, 2010). The negative impact of conflict in schools can demotivated the teachers and subsequently decrease the level of students' performance (Saiti, 2015). Poorly conflict management in the organization can negatively affect organizational commitment (Thomas et al, 2005), as well as job performance and productivity (Meyer, 2004; Trudel \& Reio, 2011). Most of the cause of conflict in organization is because of lack in communication (Messarra, Karkoulin \& El-Kassar, 2016), decision making only involved certain people, and principal still communicate by using top to down flow of information in organization (Saiti, 2013).

Terry (1996) purposed that conflict management is the most valuable tools that everybody can learn to be a good leader. Through effective conflict management training programs, collegiality can be fostered (Saiti, 2015) and principals are exposed to use variety of conflict management style as the conflict itself is specific and situational (Hopkins \& Yonker, 2015). Yusoff, Don and Ismail (2016) noted that distributed leadership plays an important role in conflict management in schools and resulting that conflict management style effects the practice of distributed leadership itself. Don et al., (2015) found that there was a significant and positive relationship between emotional competence and distributed leadership. The appointed of future school leaders should not only based on seniority and IQ competencies, but also need to appointed at emotional competence as well.

Even though various of distributed leadership literature are having positives outcomes in research and are able to build collaboration work culture and thus improve school performances (Park \& Ham, 2014), the question on how the process of distributed leadership that had been practiced in school is still being debated and less understood (De Matthews, 2014). Some of the practice of distributed leadership in school, in other way have been overpowered (Hulpia \& Devos, 2010). It is supposed that this distributed leadership have been implemented to all schools in Malaysia during the year of 2016-2020 according to the second wave of MEB (Jamail \& Don, 2016), but it is still unclear. Moreover, distributed leadership had to be fit in with the needs of the Millennial Generations (Generation $Y$ ), which the effective leadership style of this generation is becoming more complex (Spillane, Halverson \& Diamond, 2004) due to the unique characteristics of this cohort of generation. Harris (2012) simplified that interactions, situation and leadership act as critical needs in the educational changes, and it had to be fit in with the needs of the characteristics of the generation $Y$ teachers. Generation $Y$ is the most studied generational cohorts in history (Thompson, 2015) and this generation is the only generation that have unique characteristics (Raman et al. 2011). It's a crucial demand for leadership to understand these new employees to be successful in the future in organizational leadership (Meier, Austin \& Crocker, 2010).

\section{Literature Review: Distributed Leadership and Conflict Management Style}

Effective leaders will create more leaders, empower others (Tan, Tie \& Chua, 2015) and enable others to act (Daud et al., 2015; Jones et al., 2015). Distributed leadership has become the most popular leadership models of international literature in education system of the $21^{\text {st }}$ century (Harris, 2010, 2013, 2015; Harris et al., 2013; Spillane, 2005). Distributed leadership should be emphasized in schools as a platform for principals to create more 
leadership as it had a significant and positive relationship with organizational commitment (Jamail \& Don, 2016). Harris and Muijs (2003) concerned is that leadership in schools need to involve everyone in the organization. In assuring the transformation through MEB 2013 2025 becomes a successful agenda nationwide, the entire member of the organization need to change, eliminate destructive conflicts in school at every level and practiced distributed leadership. Distributed leadership provides information needed when school leadership gathered all the expertise of the members in the organization, and thus can reduce the conflict that emerged (Gronn, 2002) through collaborations.

Educational system nowadays has becoming more complex, thus generates conflict in the school environment and broadening the impact to the educational system (Sarkowi, 2012). Transformation in education system in different perspective can creates different opinions (Ahlfinger \& Esser, 2001; Kowalski et al., 2008; Kowert, 2002), decline the school achievements, reduce the passion of collaboration and team work (Kowert, 2002), turns down the trustworthy and respect to others (Kowalski et al., 2008). The predominant cause of conflicts in organization is because of the goal setting tend to be hazy (Abdullah, 2007) and lame management in the organization itself (Fabunmik \& Alimba, 2010). It is crucial for leaders to detect the extent of conflict in organization at various level (Saeed et al., 2014), as Rahim (2000) stated that conflict has a significant relationship with workloads, leadership style and school management.

In school, the role of principals has become the key factor as the leadership itself give a direct impact to the teachers (Dessler, 1994), impose the failures and the successful of the school (Bass \& Riggio, 2006). Thus principals have to root up the causes of the conflict, solving the problems and creates a conducive school environment (Yusoff, Don \& Ismail, 2016). There is also a significant relationship between teacher leadership and student achievement where teachers are potentially to become a great leader (Bakar et al., 2015). Yusoff, Don and Ismail (2016) suggested that the dimensions in distributed leadership needed to be reviewed by the teachers too, as the higher the practiced of distributed leadership, the higher the quality of the school environment will be formed. Jamail and Don (2016) also found out that the higher the practiced of distributed leadership among 3 different cohort of teacher generations in school, the higher the organizational commitments they tend to apply. Meanwhile, Man et al., (2016) found that there are a positive and significant relationship between leadership style and behavior of generation $Y$ teachers, and teachers in school are monopolized by generation $Y$ teachers that made up of $70 \%$ of the school organization. This cohort of generations will have a longer service to school organization and principals have to supervise these generation $Y$ teachers to get the best output from them (Jamail \& Don, 2019).

Generation $Y$ teachers in this study are referred as those who are born between the year of 1980 until 2000 (Beekman, 2011; Cekada, 2012; Eisner, 2005, Meier, Stephen \& Crocker, 2010; Raines, 2003). Balda and Mora (2011) depicting generation $Y$ as a very different generation with previous generations, and leaders of the organization must understand the behavior of generation $Y$ to understand their needs within the working environments. Generation $Y$ is the first generation that comes together with computers and digital media (Raines, 2002), tech savvy (Bannon et al., 2011; Beekman, 2011; Cekada, 2012), born with technology, digital savvy, independent, motivated, educated, confident and goaloriented with high expectations (Meier, Austin \& Crocker, 2010).

However, Pamu (2010) stated that early career teacher (novice teachers assumption as early cohort of generation $\mathrm{Y}$ teachers) feels initial frustration due to this high expectations 
attitude, lack of peer and school management support, assigned to handle the most challenging classes in teaching (Denscombe, 1995; Griffin et al, 1983; Sizemore et al., 1986), unsupportive work environment such as teaching loads and unavailability teaching aids and materials (Karlbers \& Fogarty, 1995), younger faculty which lead to lower organization satisfaction (Smart, 1990) and also teaching as not the priority choice as a first career (KamCheung \& Kwok-Kai, 1995). Principals need to manage these frustrations of generation $Y$ teachers by providing 'mentorship', and prevent the practice of 'old school' practices as they expect managers to be as educated as them (Meier, Austin \& Crocker, 2010).

Generation $Y$ enjoys their modern approaches working environment by using technology (Martin, 2005), but it often generates conflict with the multiple generations that appear in the workplace (Meier, Austin \& Crocker, 2010). Cekada (2012) define generation $Y$ as multitasking, able to respond feedback and hope for instant feedback in return and thus create conflict in communication with other generations in the organization. Man et al. (2016) noted that the issue of generational gap in school organization, causes the rise of the conflict to happen is school environment. Thus, bridging the gap between generation of the Baby Boomers, generation $\mathrm{X}$ and generation $\mathrm{Y}$ workers in an organization by the leaders may assist them to gear up the organizational performance by developing convenient change strategies (Bourne, 2009) and have a better understanding of individuals in an organization (Jefferies \& Hunte, 2004).

Conflict management has become a major dimension in organizational behavior and requires effective communication to negotiate when dealing with conflict (Saeed et al., 2014). It is exceptionally related to the leadership as leadership and conflict can reduce the tensions and harmonize understanding (Fisher, 2000), creating conflict-free environment, resolve crisis and motivated followers (Saeed et al., 2014). In this research, distributed leadership is highlighted among generation $Y$ teachers, as the high influence with 96.5 percent between distributed leadership and conflict management style in school environment emerged, by the study conducted by Yusoff, Don and Ismail (2016). There is also a high correlation $(r=0.86)$ between the two variables where the distributed leadership had the highest relationship with integrating conflict management style and lowest relationship with avoiding style. Avoiding conflict is often used due to the negative consequences that might emerge as it can harm the stability and consistency within the organization (Nadler \& Tushman, 1999). Jamail and Don (2019) found out that generation $Y$ teachers prefer using compromising style and less prefer to use avoiding style when it comes to conflict they faced with their principals. This is because compromising style concerned the give and take actions between the conflicting parties either win or lose (Rahim, 1983) and this approach is also known as 'win some - lose some' (Thomas \& Kilmann, 1974). Meanwhile generation $Y$ teachers tend not to use avoiding style as it then will lead to more severe conflict in the future, if no solution had been made in certain period of managing conflict (Jamail \& Don, 2019).

It is recommended by Myers and Sadaghiani (2010) that a further study needs to be done about how the attitude of the generation $Y$ workers had long-term impact on an organization based on their unique characteristics. Pamu (2010) detected an alarming issues in his research where $53 \%$ early career teachers have high intentions to quit and $13 \%$ have low quit intentions, and the major finding is because early career teachers have no identity as a teacher. These generation $Y$ teachers need to be the focus of attention of the principal in school as a good conflict manager, as it could build up a positive and conducive school environment (Yusoff, Don \& Ismail, 2016). 


\section{Findings}

The study findings and discussion are based on research questions that had been specified. Generation $Y$ teachers distributed leadership practices were analyzed and were determined either it had a significant and positive relationship with conflict management style that they faced with their principals within the school environment.

I. Is there any difference in distributed leadership practice based on demographic factors such as gender, respondents' qualifications and years of teaching experiences?

Table 1 shows the distribution of demographic variables of the study in frequency and percentage. It is interesting to note from this table that the majority of generation $Y$ teachers had degree qualification of $90.5 \%$ and Master's degree qualification of $9.5 \%$. There were no qualification of diploma and $\mathrm{PhD}$ holders involved in this study. Novice teachers are also the minority of generation $Y$ teachers involved in this study that made up only $22.2 \%$ form overall of the respondents.

Table 1: Analysis of the respondents according to demographic variables.

\begin{tabular}{lll}
\hline & Frequency & Percentage \\
\hline Gender & & \\
Male & 81 & 21.9 \\
Female & 289 & 78.1 \\
Total & 370 & 100.0 \\
Qualification & & \\
Degree & 335 & 90.5 \\
Master's Degree & 35 & 9.5 \\
Total & 370 & 100.0 \\
Years of teaching experience & & \\
1-5 years & 82 & 22.2 \\
6-10 years & 196 & 53.0 \\
11-15 years & 92 & 24.8 \\
Total & 370 & 100.0 \\
\hline
\end{tabular}

To determine whether there was any statistically significant difference in the generation $Y$ teachers distributed leadership practices with reference to their gender, an independent sample t-test was conducted. Table 2 shows that there is no significance difference in the scores for male $(M=4.02, S D=.30)$ and female $(M=4.03, S D=.31)$ teachers: $t(368)=-.10, p$ $<.92 *$ with $(p>.05)$.

Table 2: Descriptive statistics and independent sample t-test result for generation $Y$ teachers' distributed leadership practice and gender

\begin{tabular}{lllllllll}
\hline Gender & $\mathrm{N}$ & Mean & $\mathrm{SD}$ & $\begin{array}{l}\text { SE } \\
\text { Mean }\end{array}$ & $\mathrm{t}$ & $\mathrm{df}$ & $\begin{array}{l}\text { Sig } \\
\text { (2-tailed) }\end{array}$ & $\begin{array}{l}\text { Mean } \\
\text { difference }\end{array}$ \\
\hline Male & 81 & 4.02 & .30 & .03 & -.10 & 368 & $.92 *$ & -.004 \\
Female & 289 & 4.03 & .31 & .02 & & & & \\
\hline
\end{tabular}

*significant at the 0.05 level (2-tailed) 
An independent sample t-test was also conducted to determine whether there was any statistically significant difference in the way generation $Y$ teachers described their overall distributed leadership with reference to their qualifications. Table 3 shows that there was no significance difference in distributed leadership with degree qualification $(M=4.03, S D=.30)$, and Master's degree qualification $(M=4.06, S D=.38)$. These results suggest that generation $Y$ teachers' qualification has no influence on their distributed leadership practices. Based on the result, $t(368)=-0.53, p>0.05$, it shows that there is no significant difference because $(p$ $>.05)$ in terms of distributed leadership practice based on generation $Y$ teachers' qualification.

Table 3: Descriptive statistics and one sample t-test result for generation $Y$ teachers' distributed leadership practice and qualifications

\begin{tabular}{lllllllll}
\hline Qualifications & $\mathrm{N}$ & Mean & SD & $\begin{array}{l}\text { SE } \\
\text { Mean }\end{array}$ & $\mathrm{t}$ & $\mathrm{df}$ & $\begin{array}{l}\text { Sig } \\
\text { (2-tailed) }\end{array}$ & $\begin{array}{l}\text { Mean } \\
\text { difference }\end{array}$ \\
\hline Degree & 335 & 4.03 & .30 & .02 & -.53 & 368 & .594 & -.030 \\
Master's degree & 35 & 4.06 & .38 & .07 & & & & \\
\hline
\end{tabular}

*significant at the 0.05 level (2-tailed)

Based on table it is found that the one-way ANOVA test is not significant with $F(2,367)=.50$. The result also showed that the Levene test is not significant with $p=.61(p>.05)$. This shows that there is a mean difference and thus, there is no significant difference in terms of the practice of distributed leadership based on years of generation $Y$ teachers.

Table 4: One-way ANOVA results for distributed leadership practices based on years of teaching experiences

\begin{tabular}{llllllll}
\hline Years of teaching experiences & $\mathrm{N}$ & Mean & SD & df1 & df2 & $\mathrm{F}$ & $\mathrm{P}$ \\
\hline $1-5$ years & 82 & 4.04 & .27 & 2 & 367 & .50 & .61 \\
$6-10$ years & 196 & 4.01 & .31 & & & & \\
$11-15$ years & 92 & 4.05 & .34 & & & & \\
\hline
\end{tabular}

*significant at the 0.05 level (2-tailed)

II. What is the level of distributed leadership of generation $Y$ teachers in Malaysia?

In order to identify which of the seven constructs was the most prevalent among the generation $Y$ teachers, descriptive analyses were conducted to determine the means and standard deviations of the dimensions of distributed leadership. Referring to data in Table 5, the findings show that as a whole, generation $Y$ teachers displayed a high level of distributed leadership ( $M=4.03, S D=.31)$. The dimension principal leadership is found to be the highest dimension to practice $(M=4.12, S D=.51)$, followed by artifacts $(M=4.11, S D=.42)$, instructional program $(M=4.10, S D=.45)$, teacher leadership $(M=4.10, S D=.37)$, school culture $(M=4.03$, $S D=.37)$, and school vision $(M=4.02, S D=.41)$, and the lowest dimension of distributed leadership practiced by the generation $Y$ teachers is school organization $(M=3.74, S D=.42)$. 
Table 5: Mean and standard deviations of the distributed leadership dimensions.

\begin{tabular}{llll}
\hline Dimensions of Distributed Leadership & Mean & SD & Level \\
\hline School Organization & 3.74 & .42 & High \\
School Vision & 4.02 & .41 & High \\
School Culture & 4.03 & .37 & High \\
Instructional Program & 4.10 & .45 & High \\
Artifacts & 4.11 & .42 & High \\
Teacher Leadership & 4.10 & .37 & High \\
Principal Leadership & $\mathbf{4 . 1 2}$ & .51 & High \\
& & & \\
Distributed Leadership & $\mathbf{4 . 0 3}$ &. $\mathbf{3 1}$ & High \\
\hline
\end{tabular}

III. What is the level of conflict management style of generation $\mathrm{Y}$ teachers in Malaysia? Referring to data in Table 6, the findings show that as a whole, generation $Y$ teachers displayed a high level of conflict management style $(M=3.69, S D=.25)$. The dimension compromising is found to be the highest dimension in handling conflict with the principals $(M=3.98, S D=.23)$, followed by integrating $(M=3.95, S D=.27)$, obliging $(M=3.78, S D=.29)$, dominating ( $M=3.38, S D=.57)$ and the lowest dimension in handling conflict with the principal by the generation $Y$ teachers is the avoiding style $(M=3.35, S D=.62)$.

Table 6: Mean and standard deviations of the conflict management dimensions.

\begin{tabular}{llll}
\hline Dimensions of Conflict Management & Mean & SD & Level \\
\hline Integrating & 3.95 & .27 & High \\
Obliging & 3.78 & .29 & High \\
Compromising & 3.98 & .23 & High \\
Avoiding & 3.35 & .62 & Medium \\
Dominating & 3.38 & .57 & Medium \\
& & & \\
Conflict Management & $\mathbf{3 . 6 9}$ &. $\mathbf{2 5}$ & High \\
\hline
\end{tabular}

IV. Is there are any relationship between distributed leadership and conflict management style of generation $Y$ teachers in Malaysia?

Table 7: Relationship between Distributed Leadership and Conflict Management

\begin{tabular}{lll}
\hline & Distributed Ledaership & Conflict Management \\
\hline Distributed Leadership & 1 & $.354^{* *}$ \\
Conflict Management & $.354^{* *}$ & 1 \\
Significant (2-tailed) & .000 & .000 \\
\hline
\end{tabular}

**significant at the 0.01 level (2-tailed)

Table 7 shows that there is a positive and significant relationship between distributed leadership practice and conflict management style. This proves that distributed leadership has a high average relationship $(r=.354, p<0.01)$ statistically with conflict management. The positive relationship in distributed leadership affect conflict management of generation $Y$ teachers towards principal. 
V. What is the highest dimension of conflict management that shows relationship with the distributed leadership of generation $Y$ teachers in Malaysia?

Table 8: Overall Correlation between Conflict Management and Distributed Leadership

\begin{tabular}{ll}
\hline Dimensions & Distributed Leadership \\
\hline Conflict Management & $.354^{* *}$ \\
Integrating & $.266^{* *}$ \\
Obliging & $.285^{* *}$ \\
Compromising & $.391^{* *}$ \\
Avoiding & $.303^{* *}$ \\
Dominating & -0.01 \\
\hline$* * p<0.01 ;{ }^{*} p<0.05$ &
\end{tabular}

An analysis of conflict management as well as practices of distributed leadership in this study were conducted based on the Pearson correlation analysis. Based on the results of Table 8, it appears that there is a positive, significant and high average correlation at the level of $p<$ 0.05 between conflict management and distributed leadership $(r=.354 ; p<0.05)$. There is no significant relationship found between dominating dimension of conflict management with distributed leadership ( $r=-0.01 ; p>0.05$ ). The findings also indicate dimensions of compromising ( $r=.391, p>0.05)$ as having a highest significant and high average correlation to the distributed leadership practices.

\section{Discussion}

Generation $Y$ teachers displayed a high level of distributed leadership ( $M=4.03$, $S D=.31)$ with the highest dimension to practice is principal leadership ( $M=4.12, S D=.51)$ and the lowest dimension of distributed leadership practiced by the generation $Y$ teachers is, school organization ( $M=3.74, S D=.42)$. The result is in line with Rabindarang, Khuan and Khoo (2014) where the level of distributed leadership practices in technic and vocational schools are at high average level and thus can reduce stress in the organization. The highest item in the dimension of principal leadership is; 'The principal's goals are aligned with the school districts.', followed by the item 'The principal provides leadership in improving academic achievement.', and item 'The principal provides a structure that encourages all teachers to participate in improving academic achievement'. This shows that generation $Y$ teachers require direct attentions from principals (Alanezi, 2011).

According to Lee, Hung and Ling (2012), generation $Y$ preservice teachers prefer quality supervisory relationships, conducive working environment, and quality co-workers' relationships. Generation $Y$ is best described as 'informal' (Sheahan, 2005), they prefer informal leadership atmosphere that builds relationship (Kühl, Schnelle, \& Tillmann, 2005), they also prefer informal meetings and flexible workspaces (Bannon et al., 2011), they desire to be coached and enjoy having fun at work (Sheahan, 2005), thus leaders need to find the best method to manage and lead this emerging generation. Tulgan (2009) referred generation $Y$ as 'the most high-performing workforce in history' if leaders make serious efforts in managing them properly. To comprehend generational diversity in an organization these days 
are critical, as it can gain better information to understand individuals in the workplace (Jefferies \& Hunte, 2004).

High level of distributed leadership in school among teachers can boost the commitment of the teachers (Jamail \& Don, 2016). This is parallel with the necessity of the practices of distributed leadership, that leaderships need to be stretched over to individuals in the organization (Elmore, 2000; Gronn, 2002; Spillane et al., 2001). In the context of education, principals need to distribute leadership to the teachers, and encourage shared responsibility (Gronn \& Hamilton, 2004; Silins \& Mulford, 2002; Spillane \& Diamond, 2007) as empowerment towards teacher leadership may lead to a higher commitment and job satisfaction in school (Jamail \& Don, 2016; Rinehart \& Short, 1994; Somech \& Drach-Zahavy, 2000). Leaders usually feels frustrated in managing generation $Y$ because of the attitude of rejection in "we-have-always-done-it-this-way-approach" (Sheahan, 2005). Davis (2009) urged principals to analyzed ctitically the whole situation of their organization and made continuous act to build up the generation $Y$ teachers' capacity. Teachers need to be given more leadership tasks in various area in education, to ensure the successful practices of distributed leadership in schools are achieved (Jamail, 2016).

Meanwhile in conflict management, generation $Y$ teachers displayed a high level of conflict management $(M=3.69, S D=.25)$, where the dimension compromising is found to be the highest dimension in handling conflict with the principals $(M=3.98, S D=.23)$, and the lowest dimension in handling conflict with the principals by the generation $Y$ teachers is the avoiding style ( $M=3.35, S D=.62)$. The highest item in the dimension of the most desirable style in integrating of conflict management in this research is; "I use "give and take" so that a compromise can be made', followed by item 'I negotiate with my principal so that a compromise can be reached.', and item 'I usually propose a middle ground for breaking deadlocks.' Generation $Y$ teachers feel that when conflicts occur between them and the principals, they prefer to use compromising style. The style is often applied because it concerns a give and take action between both parties and no party win or lose (Rahim, 1983). Thomas and Kilmann (1974) highlighted that this compromising style motivates all parties to benefit from it and this approach is known as 'win some-lose some'. This compromising style is also founded to be moderate between the two dimensions in concerning for self and concerning for others between the conflicting parties. The two conflicting parties will then create an agreement to find a solution (Rahim, 1983).

The conflicted parties involved would exchange and shared ideas, that end up satisfying everybody that involved (Rahim, 1986). This also concerned that the individual is trying to practice two-way communication by using this style of conflict management that fits the characteristic of generation $Y$ teachers, as they always ask questions to get a rational answer due to the high curiosity that they owned (Kehril \& Sapp, 2006). They are realistic and optimistic (McNamara, 2005), seek desired output as they are a generation that is based on end result-oriented (Streeter, 2007).

In this research of conflict management style, the avoiding dimension became the most undesirable conflict management style with the lowest mean score of 3.35. Generation $Y$ teachers are not individuals who tend to avoid, withdraw, disagreement, engage in debates, impolite communication, defer conflicts, do not accentuate themselves and seek other solutions by means of this avoiding style (Rahim, 1983). Generation $Y$ teachers always demand immediate answers and feedback on the task assigned as they are responsible in whatever they are involved (Martin, 2005). The administration should establish relevant work space 
and draw the attention of generation $\mathrm{Y}$ teachers since the nature of this cohort who demands attention and immediate feedback (Jane et al., 2009). Although this avoiding style can be adapted to conflict situations, the consequent of a slow decision will interfere with any decision to be made later (Gross \& Guerrero, 2000; Goodwin, 2002; Rahim, 2004). This is against the individual characteristics of the generation $Y$ who always require immediate feedback and decisions.

There is no significant difference between gender, qualifications and years of teaching experiences found in this research. Through gender, the finding on this study is in line with Jamail (2016), Zakaria and Kadir (2013), Othman and Said (2013) in Malaysian school context, where there is no significant difference between male and female teachers in practicing distributed leadership. However, the finding in this study is not in line with Nguyen (2013) where there was a significant difference between gender. Male teachers have a higher commitment to practice distributed leadership rather than the female teachers in Vietnam. Nguyen (2013) stated the main result of his findings is that male teachers have a higher opportunity to work rather than the female teachers, namely because of the factor of the Vietnam's culture.

There is no_significant difference in distributed leadership with degree qualification $(\mathrm{M}=4.03, \mathrm{SD}=.30)$, and Master's degree qualification $(\mathrm{M}=4.06, \mathrm{SD}=.38)$. These results suggest that generation $Y$ teachers' qualification has no influence on their distributed leadership practices, even though Tulgan and Martin (2001) noted that generation $Y$ obtained higher education than the previous education. In terms of years of teaching experiences, there were also no significant difference in practicing distributed leadership among generation $Y$ teachers. Halim and Ahmad (2015) stated that the teachers are ready to apply their leadership with their capability and capacity regardless of their teaching experiences. Halim and Ahmad (2015) also noted that secondary school and boarding schools showed a higher mean (4.15) in practicing distributed leadership rather than other schools in Malaysia (Premier boarding schools, Integration boarding schools, Sekolah Menengah Sains and Sekolah Menengah Agama Persekutuan). 83\% teachers agreed to practice distributed leadership and they are ready to implement it in their school.

Overall, there is a high average of correlation value between distributed leadership practices with the dimensions of conflict management in integrating style $(r=.39)$, followed by avoiding style $(r=.30)$, obliging style $(r=.29)$ and compromising style $(r=.27)$. However, there is no relationship found between distributed leadership practices with dominating style $(r=-0.01)$.

\section{Conclusion}

As a conclusion, it is hoped that this research can provide guidance for both principals and generation $Y$ teachers, in an open view of the current research of generational gap knowledge in leadership and managing the arisen of generational conflict. Bridging the generational gap is an important agenda in managing changes in education and it can no longer be ignored (Bannon, et al., 2011; Putre, 2013; Reisenwitz \& lyer, 2009). Generational conflict in organization were increasing and had been documented (Tulgan, 2004). The retirement of generation Baby Boomers (in this research appointed to the principals), relatively smaller size of workforce in generation $X$, makes the cohort of generation $Y$ becomes a high demand in the job market (Kilber, Barclay \& Ohmer, 2014). Being aware of the perceptions, needs, requirements, capacity, communication, leadership and conflict 
management style that this generation $Y$ preferred, principals are able to achieve the visions they desired alongside with them. Therefore, efforts should be multiplied to increase the extensive comprehension of distributed leadership practices and the importance of conflict management in generation $Y$ teachers, regardless of their gender, qualification and years of teaching experiences. Leadership and conflict management can be learned, because both are basic requirements for lifelong learning in individuals to survive in their workplace. MEB 20132025 is currently in the second wave of the implementation (2016-2020), where it clearly stated to elevate the profession and moving towards distributed leadership. This is what we in the educational sectors urged to achieved in the fifth shift through MEB that is: Ensure high performing school leaders in every school.

\section{Corresponding Author}

Yahya Don, School of Education and Modern Languages, Universiti Utara Malaysia, UUM PhD (Educational Leadership)

Farah Mohd Zain, School of Education and Modern Languages, Universiti Utara Malaysia, UUM

PhD (Educational Leadership)

\section{References}

Abdullah, A. S. (2007). Apakah Sekolah Kluster adalah Sekolah Berkesan? Kertas Ucap Utama Seminar Pendidikan Kebangsaan Fakulti Pendidikan. Universiti Malaysia.

Abdullah, J. B., \& Kassim, J. M. (2011). Instructional leadership and attitude towards organizational change among secondary school's principal in Pahang, Malaysia. Procedia Social and Behavioral Sciences, 15, $3304-3309$.

Abdullah, N. A. W., DeWitt, D., \& Alias, N. (2013). School improvement efforts and challenges: A case study of a principal utilizing information communication technology. ProcediaSocial and Behavioral Sciences, 103, 791-800.

Ahlfinger, N. R. \& Esser, J. K. (2001). Testing the groupthink model. Effects of promotional leadership and conformity predisposition. Social Behavior \& Personality: An International Journal. 29(1). 31-42.

Alanezi, A. S. (2011). Communication satisfaction and its relationship to organizational commitment among secondary school teachers in Kuwait. (Unpublished doctoral dissertation). Indiana State University, Indiana.

Alch, M. L. (2008). Get Ready for a new type of workplace: the net generation. Supervision. 69(6), 18-21.

Al-Hamdan, Z., Norrie, P., \& Anthony, D. (2012). Conflict management styles used by nurses in Jordan, Journal of Research in Nursing, 19 (1), 40-53.

Anthony, S., Said, H., Mohamad, I., \& Mokhtar, M. (2015). Self-efficacy belief as a practical and parsimonious evaluation criterion in school leadership training. Mediterranean Journal of Social Sciences, 6(1), 20.

Ayoko, O. B, \& Konrad, A. M. (2012). Leaders' transformational, conflict, and emotion management behaviors in culturally diverse workgroups, Equality, Diversity and Inclusion: An International Journal, 31(8), 694-724.

Bakar, N. A., Basri, R., \& Fooi S. F. (2015). Hubungan kepimpinan guru dengan pencapaian akademik pelajar. International Journal of Education and Training. 1(2). 1-11. 
Balda, J., \& Mora, F. (2011). Adapting leadership theory and practice for the networked, millennial generation. Journal of Leadership Studies, 5, 13-24. doi:10.1002/jls.20229

Bannon, S., Ford, K., \& Meltzer, L. (2011). Understanding Millennials in the workplace. CPA Journal, 81(11), 61-65.

Bass, B. M., \& Riggio, R. E. (2006). Transformational Ledaership, 2nd ed., Lawrence Erlbaum, Mahwah, NJ.

Beekman, T. (2011). Fill in the generation gap. Strategic Finance, 93(3), 15-17.

Boon, Y. \& Tahir, Y. (2013). Kepimpinan tersebar dan hubungannya dengan tekanan dan komitmen kerja. Johor: Universiti Teknologi Malaysia.

Bourne. B. B. (2009) Phenomenological study of response to organizational change: Baby boomers, generation $X$ and generation $Y$. Doctoral of Management of Organizational Leadership. University of Phoenix. UMI Number:3357438

Bush, T. (2011). Theories of educational leadership \& management (4th ed.). London: Sage.

Bush, T., \& Glover, D. (2012). Distributed leadership in action: Leading high-performing leadership teams in English schools. School Leadership \& Management, 32(1), 21-36. doi:10.1080/ 13632434.2011.642-4

Carter, K., Macdonald, G. \& Martin, A. (2006). Distributed Leadership in discussion. Paper presented at the 1st international Conference, NSCL, Nottingham.

Cekada, T. L. (2012). Training a multigenerational workforce. Professional Safety, 57,40-44.

Davis, M. W. (2009). Distributed Leadership and School Performance. Unpublished doctoral dissertation. The faculty of the Graduate School of Education and Human Development of the George Washington University, UMI Number 3344534.

Daud, Y., Yusoff, Z. J. M., Khalid, R., Don, Y., Fauzee, M. S. O., Raman, A. \& Hussin, F. (2015). Distributive Leadership Among Leaders in Effective Schools. Journal of Teaching and Education, 04(03), 423-433. ISSN:2165-6266.

DeMatthews, D. (2014). Principal and Teacher Collaboration: An Exploration of Distributed Leadership in Professional Learning Communities. International Journal of Educational Leadership and Management, 2(2), 176-206. doi: 10.4471/ijelm.2014.16

Denscombe, M. (1985). Classroom Control: A Sociological Perspective, Allen \& Unwin, London. Dessler, D. (1994). How to Sort Causes in the Study of Environmental Change and Violent Conflict in Environment, Poverty, Conflict in Nina Gr. Leger \& Dan Smith. International Peace Research Institute Oslo, 4: 91-112.

Don, Y. (2009). Korelasi dan pengaruh kompetensi emosi terhadap kepimpinan sekolah: Perbandingan antara sekolah berkesan dengan sekolah kurang berkesan. Tesis Dr. Falsafah. Universiti Malaya.

Don, Y., Raman, A., Daud, Y., Kasim, K., \& Fauzee, M. S. O. (2015). Educational Leadership Competencies and Malaysia Education Development Plan 2013-2025. Humanities and Social Sciences Review, 615-625.

Eisner, S. P. (2005). Managing Generation Y. SAM Advanced Management Journal, 70(4), 415.

Elmore, R. (2000). Building a new structure for school leadership. Washington: The Albert Shanker Institute.

Fabunmi, M. \& Alimba, C. N. (2010). Conflict in School Climate: A Synopsis of Its Nature, Causes, Effects and Management Approaches. African Journal of Educational Management, 13(2), 205-226. 
Farahani, M. (2011). An exploration of the relationship between transformational leadership and organizational commitment: The moderating effect of emotional intelligence: Case study in Iran. International Business Research, 4(4), 211-217.

Fisher, R. J. (2000). Intergroup Conflict. The Handbook of Conflict Resolution, Jossey-Bass Publishers, San Francisco, CA, 166-185.

Fullan, M. (2007). The new meaning of educational change. New York: Teachers College Press.

Ghani, M. F. A. (2013). Educational Management in Malaysia. Kuala Lumpur. University of Malaya Press.

Goodwin, J. (2002). Auditors 'conflict management style: An exploratory study. Abacus, 38 (3), 378-405.

Green, R. L. (2009). Practicing the art of leadership: A problem-based approach to implementing the ISLLC standards. ( $3^{\text {rd }}$ ed.). Pearson.

Griffin, G. A., Barnes, S., Hughes, R., O'Neil, S., Defino, M. E. \& Hukill, A. (1983). Clinical Preservice Teacher Education: Final Report to the National Institute of Education, University of Texas, Austin.

Gronn, P. (2002). Distributed leadership as a unit of analysis. The Leadership Quarterly, 13, 423-451, doi:10.1016/s1048-9843(02)00120.

Gronn, P. \& Hamilton, A. (2004). A bit more life in the leadership: Co-principal ship as distributed leadership practice. Leadership and Policy in School. 3(1), 3-35.

Gross, M. A., \& Guerrero, L. K. (2000). Managing conflict appropriately and effectively: An application of the competence model of Rahim 's organizational conflict styles. International Journal of Conflict Management, 11(3), 200-226.

Halim, R. A., \& Ahmad, H. (2015). Kepemimpinan Distributif, Faktor Kontekstual dan Efikasi Kendiri Guru Malaysia. Jurnal Kepimpinan Pendidikan, Institut Aminuddin Baki, Genting Highlands, 2(4).

Hall, G. E. \& Hord, S. M. (2001). Implementing change: Patterns, principles and potholes. Boston, MA: Allyn \& Bacon.

Harris, A., (2012), Distributed leadership: implications for the role of the principal, Journal of Management Development, 31(1), 7-17.

Harris, A. (2010). Distributed leadership: Current evidence and future directions. In T. Bush, L. Bell, \& D. Middle wood (Eds.), The principles of educational leadership and management (pp. 55-70). London: Sage.

Harris, A. (2013). Distributed leadership matters: Perspectives, practicalities, and potential. Thousand Oaks, CA: Corwin Press.

Harris, A., \& Muijs, D. (2003). Teacher leadership: Improvement through empowerment? An overview of the literature Educational Management an Administration, 31, 437-448.

Harris, A., Jones, M., Sharma, S., \& Kannan, S. (2013). Leading educational transformation in Asia: Sustaining the knowledge society. Asia Pacific Journal of Education, 33(2), 212221. doi:10.1080/02188791.2013.782802

Harris, A. (2013). Distributed Leadership: Friend or foe? Educational Management Administration and Leadership. 41, 545.

Hendel, T. (2005). Leadership styles and choice of strategy in conflict management among Israeli nurse managers. Journal of Nursing Management. 13(2), 137-145.

Hopkins, M. M. \& Yoner, R. D. (2015). Managing Conflict with Emotional Intelligence: Abilities that make a difference. Journal of Management Development, 34(2), 226 -244. 
Hulpia, H., Devos, G., \& Keer, H. V. (2010). The influence of distributed leadership on teachers' organizational commitment: A multilevel approach of Educational Research, 103, 4052.

Jamail, M., \& Don, Y. (2019). Gen-Y Teacher Leadership on Conflict Management and Communication Satisfaction. International Journal of Academic Research in Business and Social Sciences, 9(1), 881-897.

Jamail, M., \& Don, Y. (2016). Praktis Kepimpinan Distributif Dan Komitmen Terhadap Organisasi Berdasarkan Kohort Generasi Guru. International Seminar on Generating Knowledge Through Research UUM-UMSIDA ,Proceeding of ICECRS, Universiti Utara Malaysia, 1, 275-286. ISSN. 2548-6160.

Jane, W. G., Regina, A. G., Edward, F. M. (2009). Generational Differences In The Workplace: Personal Values, Behaviors, And Popular Beliefs, Journal of Diversity Management. 4 (3). 1-7.

Jefferies, F. L., \& Hunte, T. L. (2003). Generations and motivation: A connection worth making. Journal of Behavioral and Applied Management, 6(1), 37-70.

Jones, M., \& Harris, A. (2014). Principals leading successful organizational change: Building social capital through disciplined professional collaboration. Journal of Organizational Change Management, 27(3), 473-485. doi:10.1108/JOCM-07-2013-0116

Jones, M., Adams, D., Joo, M. T. H., Muniandy, V., Perera C. J., \& Harris, A. (2015). Contemporary challenges and changes: principals' leadership practices in Malaysia. Asia Pacific Journal of Education, 35(3), 353-365, DOI: 10.1080/02188791.2015.1056591

Kam-Cheung, W. \& Kwok-Kai, L. (1995). Teacher turnover and turnover intentions in Hong Kong and aided secondary schools. Educational Research Journal, 10(1), 36-46.

Kalbers, L. P., \& Fogarty, T. J. (1995), Professionalism and its consequences: a study of internal auditors. Auditing: A Journal of Practice and Theory, 14(1), 64-86.

Katzenmeyer, M. \& Moller, G. (2009). Awakening the Sleeping Giant: Helping Teacher Develop as Leaders (3rd edition). CA: Corwin.

Kehril, S. \& Sapp, T. (2006). Managing generation Y. HR Magazines, 51(5). 113.

Kilber, J., Barclay, A., \& Ohmer, D. (2014). Seven Tips for Managing Generation Y. Journal of Management Policy and Practice, 15(4). 80 - 91.

Kowalski, C. J. \& Cangemi, J. P. (2008). Developing trust and distrust in higher education. Psychology and Education: An Interdisciplinary Journal, 45(3-4), 21-32.

Kowert, P. A. (2002). Groupthink or deadlock: When Do Leaders learn from their advisors? Albany: Blackwell Publishing.

Kühl, S., Schnelle, T., \& Tillman, F. (2005). Lateral leadership: An organizational approach to change. Journal of Change Management. 5(2). 17 - 189. doi: 10.1080/146970105000982015

Lee C. S., Hung, D. K. M., \& Ling T. C. (2012). Work values of Generation Y preservice teachers in Malaysia. International Congress on Interdisciplinary Business and Social Science 2012. Procedia - Social and Behavioral Sciences, 65, 704 - 710. doi:10.1016/j.sbspro.2012.11.87

Lizotte. J. O. (2013). A Qualitative Analysis of Distributed Leadership and Teacher Perspective of Principal Leadership Effectiveness. Doctor of Education. Northeastern University, Boston, Massachutes. 
Mahmud, A. G. (2011). Haluan Kerja Pendidikan : Merealisasikan Agenda Transformasi Negara. Kementerian Pendidikan Malaysia.

Man, J., Don, Y., \& Ismail, S. N. (2016). Hubungan Kepimpinan sekolah dengan tingkah laku guru generasi Y. International Seminar on Generating Knowledge Through Research, 1, 155-166. ISSN:2548-6160.

Doi:http://d.doi.org/10.21070/picecrsv1i1.592.

Mansor, A. N. (2006). Amalan Pengurusan Pengetua: Satu Kajian Kes. Tesis ljazah Doktor Falsafah. Universiti Kebangsaan Malaysia. Tidak diterbitkan.

Martin, C. A. (2005). From high maintenance to high productivity: What managers need to know about Generation Y. Industrial and Commercial Training, 37(1), 39-44.

Martin, C. A. (2007). The future of leadership: Where do we go from here? Industrial and Commercial Training. 39(1). 7-17.

Malaysian Education Blueprint. (2012). Malaysia Education Blueprint: 2013-2025.

McNamara, S. (2005). Incorporating generational diversity. Association of Operating Room Nurses. AORN Journal, 81, 1149-1153

Meier. J., Austin, S. F., \& Crocker, M. (2010). Generation Y in the Workforce: Managerial Challenges. The Journal of Human Resource and Adult Learning, 6(1). 68-78.

Messarra, L. C, Karkoulian, S., \& El-Kassar, A. (2016). Conflict resolution styles and personality. International Journal of Productivity and Performance Management, 65(6), 792-810.

Murji, S. (2015). Taking followership education to the next level. Journal of Leadership Education, 14, 168-177.

Myers, K. K., \& Sadaghiani, K. (2010). Millenials in the workplace: A communication perspective on millenials' organizational relationship and performance. Journal of Business Psychology. 25, 225-238. Doi 10.1007/s10869-010-9172-7.

Nayeem, M. S. A. (2011). Perception of effective in Bangladesh secondary schools: moving towards Distributed Leadership. Unpublished Master of Education thesis, College of Education, University of Canterbury, Christchurch.

Nguyen, N. D. (2013). The Influence of Distributed Leadership On Teacher Organizational Commitment: Initial Evidence From Vietnam, Arecls, 10, 69-90.

Othman, N., \& Said, R. M. (2013). Tahap Kesediaan guru sekolah menengah harian mengamalkan kepimpinan tersebar. Jurnal Teknologi. 64(1), 93-100.

Pamu, M. R. (2010). Early career teachers' quit intentions: implications for teacher education. International Journal of Educational Management,24(6), 478491. https://doi.org/10.1108/09513541011067665

Park, J. H., \& Ham, S. H. (2014). Whose Perception of principal instructional leadership? Principal-teacher perceptual (dis)agreement and its influence on teacher collaboration. Asia Pacific Journal of Education, 1-20. doi:10.1080/02188791.2014.961895

Putre, L. (2013). Generations in the workplace. (cover story). H\&HN: Hospitals \& Health Networks, 87(1), 26-31.

Rahim, M. A. (1983). Measurement of organizational conflict. The Journal of General Psychology, 109(2), 189-199.

Rahim, M. A. (1986). Referent role and styles of handling interpersonal conflict. The Journal of Social Psychology, 126(1), 79-86.

Rahim, M. A. (2001). Managing conflict in organizations (3rd ed.). Westport, CT: Quorum Books. London: Greenwood Publishing Group, Inc 
Rahim, M. A. (2000). Empirical Studies on Managing Conflict. International Journal of Conflict management. 11(1). 5-8.

Rahim, M. A. (2004). Rahim organizational conflict inventories: Professional manual. Bowling Green, KY: Center for Advanced Studies in Management.

Raines, C. (2002). Managing Millennials. http://www.generationsatwork.com/ articles/millennials.htm.

Raines, C. (2003), Connecting Generations: The Sourcebook, Crisp Publications, Menlo Park, CA.

Raman, G., Ramendran, C., Beleya, P., Nodeson, S. \& Arokiasamy, L. (2011). Generation Y in Institution of Higher Learning. International Journal of Economics \& Business Modeling, 2(2), 142-148.

Reisenwitz, T. H., \& Iyer, R. (2009). Differences in Generation X and Generation Y: Implications for the organization and marketers. Marketing Management Journal, 19(2), 91-103.

Rinehart, J. S. M., \& Short, P. M. (1994). Job satisfaction and empowerment among teacher leaders, reading recovery teachers, and regular classroom teachers. Education, 114, 570-580.

Saeed, T., Almas S, Anis-UI-Haq M. \& Niazi G. S. K. (2014). Leadership styles: Relationship with Conflict Management Style. International Journal of Conflict Management. 25(3). 214225. DOI:10.1108?IJCMA-12-2012-0091.

Saiti, A. (2012). Reforms in Greek education 1911-2011: Reforms or something else? Ejournal of education policy. Spring. 1-10.

Saiti, A. (2015). Conflicts in Schools, Conflict Management Styles and the Role of the School Leaders: A Study of Greek Primary School Educators. Educational Management Administration \& Leadership, 43(4). $582-609$

Santhidran, S. Chandran, V. G. R. \& Borromeo, J. (2013). Enabling organizational change Leadership, commitment to change and the mediating role of change readiness. Journal of Business Economics \& Management, 14(2), $348-363$.

Sarkowi, A. (2012). Penilaian Program Praktikum: Model pembentukan dan peningkatan kualiti guru praperkhidmatan di institut pendidikan guru Malaysia. Thesis PhD. UUM.

Sheahan, P. (2005). Generation Y: Thriving (and surviving) with Generation Y at work. Victoria, Australia: Hardie Grant Books.

Shih, H. A. \& Susanto, E. (2010). Conflict management Styles, emotional Intelligence and job performance in public organizations. International Journal of Conflict Management, 21(2). 147-168.

Silins, H. \& Mulford, W. (2002). Leadership and school results. in Leithwood, K. and Hallinger, P. (Eds), Second International Handbook of Educational Leadership and Administration, Kluwer, Dordrecht, 561-612.

Rabindarang, S., Khuan, W. B., \& Khoo, Y. Y. (2014). Refleksi tenaga pengajar terhadap kepemimpinan distributif dan tekanan kerja dalam pendidikan teknik dan vokasional. Jurnal Akademika, 84(1\&2). 17-27.

Rabindarang, S., Khuan, W. B., \& Khoo, Y. Y. (2015). The Demands and Influence of Leadership on Educational Changes. Jurnal Pendidikan Malaysia, 40(1). 83-88.

Sizemore, B., Brossard, C. A. \& Harrigan, B. (1986). An Abashing Anomaly: The high Achieving Predominantly Black Elementary School, Macon University Press, Washington, DC.

Smart (1990). A Causal Model of Faculty Turnover Intentions. Research in Higher Education, 31(5), 405-424. 
Somech, A., \& Drach-Zahavy, A. (2000). Understanding extra-role behavior in schools: The relationship between job satisfaction, sense of efficacy, and teachers' extra role behavior. Teaching and Teacher Education, 16, 649-659.

Sparks, D. (2003). Change Agent: An Interview with Michael Fullan. Journal of Staff development, 24(1), 55-58.

Spillane, J. P., Halverson, R. \& Diamond, J. B. (2001). Investigating School Leadership Practices. Educational Researcher, 30(3), 23-28.

Spillane, J. P., Halverson, R., \& Diamond, J. B. (2004). Towards a theory of leadership practice: A Distributed perspective. Journal of Curriculum Studies, 36, 3-34. doi:10.1080/0022027032000106726

Spillane, J. P. (2005). Distributed leadership. The Educational Forum, 69, 143-150. doi:10.1080/00131720508984678.

Spillane, J. P., \& Diamond, J. B. (2007). Distributed Leadership in Practice; Teachers College Press: New York, NY, USA.

Streeter, B. (2007). Welcome to the new workplace. ABA Banking Journal, 99(2), 7.

Stronge, J. S., Ward, T. J., Grant, L. W. (2011). What Makes Good Teachers Good? A CrossCase Analysis of the Connection between Teacher Effectiveness and Student Achievement. Journal of Teacher Education, 62(4). 339-355. DOI:10.1177/0022487111404241.

Sy, T. (2010). What do you think of followers? Examining the content, structure, and consequences of implicit followership theories. Organizational Behavior and Human Decision Processes, 113, 73-84.

Tahir, L. M., Lee, S. L., Musah, M. B., Jaffri, H., Said, M. N. H. M \& Yasin, M. H. M. (2016). Challenges in distributed leadership: evidence from the perspective of headteachers. International Journal of Educational Management, 30(6), 848-863.

Tan, M., Tie, F. H., \& Chua, Y. P. (2015). A qualitative analysis of the leadership style of a vicechancellor in a private university in Malaysia. SAGE Open, 5(1), 1-11. doi:10.1177/

Terry, P. M. (1996). Conflict Management. The Journal of Leadership Studies, 3(2), 3-18.

Thomas, K. W. (1976). Conflict and Conflict Management, Handbook of Industrial and organizational psychology. New York. Wiley \& Sons. 889-935.

Thomas, K. W., \& Kilmann, R. H. (1974). Thomas-Kilmann conflict mode instrument. Tuxedo, NY: XICOM.

Thomas, J. L., Bliese, P. D. \& Jex, S. M. (2005). International conflict and organizational commitment: examining two levels of supervisory support as multilevel moderators. Journal of Applied Psychology, 35. 2375 - 2398.

Thompson, E. (2015). Disillusionment and Generation Y. Masters of Art in Counseling Psychology, Pacific Graduate Institute. UMI Number: 1692028

Tie, F. H. (2012). Leadership for learning in Malaysian schools. In T. T. A. J. MacBeath (Ed.), International handbook of leadership for learning, Dordrecht Heidelberg: Springer. 419-429.

Torrance, D. (2012). Distributed Leadership in Scottish primary schools: myth or actualities. Unpublished Doctor of Philosophy Thesis. The Morray House School of Education, The University of Edinburgh.

Trudel, J. \& Reio, T.G. J. (2011). Managing workplace incivility: the role of conflict management styles - antecedent or antidote? Human Resources Development Quarterly. 22(4). 395-423. 
Tulgan, B. (2009). Not everyone gets a trophy: How to manage Generation Y. San Francisco, California: Jossey-Bass.

Tulgan, B. (2004). Trends point to a dramatic generational shift in the future workforce. Employment Relations Today, 30(4), 23-31.

Tulgan, B., \& Martin, C. (2001). Managing Generation Y: Global citizens born in the late seventies and early eighties. Amherst, Massachusetts: HRD Press, Inc.

Uzun, T. \& Ayik, A. (2017). Relationship between communication competence and conflict management styles of school principals. Eurasian Journal of Educational Research, 68, 167-186.

Yahaya, A., Yahaya, N., Arshad, K., Ismail, J., Jaalam, S. \& Zakariya, Z. (2009). Occupational stress and its effects towards the organization management. Journal of Social Sciences. 5(4), $390-397$.

Yukl, G. A., (2002). Leadership in organizations. Fifth edition, upper Saddle River, NJ, Prentice Hall.

Yusoff, Z. J. M., Don, Y., \& Ismail, S. N. (2016). Pengaruh kepimpinan distributif terhadap pengurusan konflik dalam kalangan pemimpin sekolah. Jurnal Pendidikan Malaysia, 41(2). 165-171.

Zakaria, N. A., \& Kadir, S. A. (2013). Kepimpinan Distributif Sekolah Menengah Di Daerah Kangar, Perlis, Seminar Pasca Siswazah Dalam Pendidikan (GREDUC 2013) Universiti Putra Malaysia. 